\title{
SELECTION OF MESOAMERICAN COMMON BEAN LINES FOR FAST COOKING AND MINERAL BIOFORTIFICATION ${ }^{1}$
}

\author{
NERINÉIA DALFOLLO RIBEIRO ${ }^{2 *}$, GREICE ROSANA KLÄSENER ${ }^{2}$
}

\begin{abstract}
Developing fast-cooking, mineral-biofortified common bean lines represents an important innovation for breeding programs. Thus, this study was conducted to determine whether elite Mesoamerican common bean lines differ for cooking time and mineral concentration and to select fast-cooking, mineralbiofortified lines. The experiments were carried out in two growing seasons, in which 16 common bean genotypes were evaluated. Cooking time was determined using a Mattson cooker, and the minerals were analyzed by acid digestion. The resulting data were subjected to individual analysis of variance, combined analysis of variance, clustering by the Scott-Knott test, and selection index (multiplicative). There was a significant genotype $\times$ environment interaction effect for cooking time and the concentrations of potassium, iron, zinc and copper. Only the phosphorus concentration showed no genetic variability between the common bean lines. The ranking of the best common bean lines differed for all traits examined in the different environments, according to the Scott-Knott test. The use of the multiplicative selection index allows selecting superior common bean lines for all traits, namely, DF 07-11, DF 08-21, DF 08-20 and DF 08-28. These lines exhibit a very short cooking time (up to $15 \mathrm{~min}$ ), high potassium concentration ( $>12.00 \mathrm{~g} \mathrm{~kg}^{-1}$ of dry matter) and the highest mean values of micromineral concentration, and will thus be selected by the breeding program.
\end{abstract}

Keywords: Phaseolus vulgaris. Genetic variability. Scott-Knott test. Selection index.

\section{SELEÇÃO DE LINHAGENS DE FEIJÃO MESOAMERICANO DE COZIMENTO RÁPIDO E BIOFORTIFICADAS PARA MINERAIS}

RESUMO - O desenvolvimento de linhagens de feijão com cozimento rápido e biofortificadas para minerais representa uma importante inovação nos programas de melhoramento. Os objetivos deste trabalho foram avaliar se linhagens elite de feijão Mesoamericano diferem para tempo de cozimento e concentração de minerais e selecionar linhagens com cozimento rápido e biofortificadas para minerais. Os experimentos foram conduzidos em duas épocas de cultivo, possibilitando a avaliação de 16 genótipos de feijão. O tempo de cozimento foi determinado em um cozedor de Mattson e a concentração de minerais foi analisada por digestão ácida. Os dados obtidos foram submetidos às análises de: variância individual, variância conjunta, agrupamento pelo teste de Scott-Knott e índice de seleção (multiplicativo). Efeito significativo da interação genótipo $\mathrm{x}$ ambiente foi observado para o tempo de cozimento e concentração de potássio, ferro, zinco e cobre. Apenas para a concentração de fósforo não se observou variabilidade genética entre as linhagens. A classificação das melhores linhagens de feijão não foi igual para todos os caracteres avaliados nos diferentes ambientes, quando se usou o teste de Scott-Knott. A aplicação do índice multiplicativo possibilita a seleção das linhagens superiores para todos os caracteres: DF 07-11, DF 08-21, DF 08-20 e DF 08-28. Essas linhagens de feijão apresentam cozimento muito rápido (até $15 \mathrm{~min}$ ), alta concentração de potássio $\left(>12,00 \mathrm{~g} \mathrm{~kg}^{-1}\right.$ de matéria seca - MS) e os maiores valores médios de concentração de microminerais e serão selecionadas pelo programa de melhoramento.

Palavras-chave: Phaseolus vulgaris. Variabilidade genética. Teste de Scott-Knott. Índice de seleção. 


\section{INTRODUCTION}

Common bean (Phaseolus vulgaris L.) is a typical dish in the cuisine of several countries. Recent studies have highlighted the high nutritional value of common bean and described its numerous benefits to health when included in the diet (SUÁREZ-MARTÍNEZ et al., 2016; CHÁVEZMENDOZA; SÁNCHEZ, 2017). Consumption of common bean is related to tradition, culture, popular beliefs and healthy dietary practices. In addition, because this food has been incorporated into the consumption habit of large population groups, it is a promising food crop for genetic biofortification programs. In Brazil, the per capita consumption of common bean is $17 \mathrm{~kg}$ inhabitant $^{-1}$ year $^{-1}$ (MAPA, 2018).

Common bean has the potential to reach an even higher consumption level if its cooking time can be shortened, since this aspect represents practicality in the preparation of a meal and less energy-spending in grain processing. To meet this demand, common-bean breeding programs have adopted the cooking time of $30 \mathrm{~min}$ as standard to achieve the softness considered suitable for consumption, in the selection of superior lines (PERINA et al., 2014; SILVA et al., 2016; PEREIRA et al., 2017). However, it has been possible to select common bean lines that can be cooked in less than 15 min (FARINELLI; LEMOS, 2010; RIBEIRO et al., 2013a, b; STECKLING et al., 2017), which represents technological advances for the common bean crop. Nevertheless, cooking time in common bean lines varies according to the cultivation year, meteorological conditions of the environment and storage time (ARNS et al., 2018), and hence the importance of carrying out experiments in different environments to improve the efficiency of selection for this trait.

If, in addition to fast cooking, a new common bean cultivar is nutritionally superior, it will contribute to improving the health of people who include this food in their habitual diet. With respect to minerals, most studies have focused on the development of common bean lines with higher iron (AKOND et al., 2011; SILVA et al., 2012; RIBEIRO et al., 2013a, 2019; STECKLING et al., 2017) and zinc (TRYPHONE; NCHIMBI-MSOLLA, 2010; SILVA et al., 2012; PEREIRA et al., 2014; MAZIERO; RIBEIRO; STORCK, 2015; MARTINS et al., 2016) concentrations. This is because deficiencies of these microminerals affect a great number of people around the world. Iron deficiency is the main cause of anemia (AL-FARTUSIE; MOHSSAN, 2017) and zinc deficiency is associated with depression and anorexia (SOUSA et al., 2019).

However, other minerals also are vital to health, e.g., potassium, which contributes to the prevention of high blood pressure (EKMEKCIOGLU et al., 2016); phosphorus, which maintains the integrity of bones and teeth (PRAVST, 2011); and copper, which acts in the maintenance of white blood cells (AL-FARTUSIE; MOHSSAN, 2017). The development of common bean lines with high concentrations of those minerals is still very recent and restricted to biofortification with potassium and phosphorus (MAZIERO; RIBEIRO; STORCK, 2015; RIBEIRO et al., 2019; RIBEIRO; MEZZOMO; SANTOS, 2019). Thus, the absorption, bioavailability and retention of these minerals in common bean lines must be investigated.

Developing fast-cooking, mineral-biofortified common bean cultivars is a technological innovation in breeding programs. The release of these cultivars has economic, social and public health impacts. Therefore, the present study was undertaken to investigate whether elite Mesoamerican common bean lines differ for cooking time and mineral concentration as well as to select fast-cooking, mineral-biofortified lines using the selection index.

\section{MATERIAL AND METHODS}

Two experiments were carried out in the experimental area of the Plant Science Department at the Federal University of Santa Maria (UFSM), in Santa Maria - Rio Grande do Sul, Brazil (29\%42 'S latitude, 53 $49^{\prime} \mathrm{W}$ longitude and $95 \mathrm{~m}$ altitude). The climate in the region is classified as $\mathrm{Cfa}$, humid subtropical, with usually well-distributed rainfall over the year. The soil in the experimental area is a typic alitic Argisol, Hapludalf, that was prepared conventionally.

The experimental layout was a randomizedblock design with three replicates. Each plot consisted of two $4.0-\mathrm{m}$-long rows, spaced $0.50 \mathrm{~m}$ apart, totaling $4 \mathrm{~m}^{2}$ of usable area. The evaluated treatments consisted of 16 common bean genotypes, of which 13 were elite lines obtained from the Bean Breeding Program of UFSM, and three cultivars, namely, Pérola, BRS Valente, and Guapo Brilhante, used as control. The control cultivars are registered for growing in the state of Rio Grande do Sul and are produced by several farmers in the southern region of Brazil. These genotypes come from the Mesoamerican gene pool and the grains are of the carioca (beige seed coat with brown streaks) and black types, the most widely produced and consumed types of common bean in Brazil.

The experiments were established in two growing seasons: rainy (October 23, 2014) and dry (February 24, 2016). Soil analysis revealed the following chemical composition: $\mathrm{pH}\left(\mathrm{H}_{2} \mathrm{O}\right)$ of 6.1 ; $18 \mathrm{~g} \mathrm{~kg}^{-1}$ organic matter; $12.7 \mathrm{mg} \mathrm{dm}^{-3} \mathrm{P} ; 80 \mathrm{mg} \mathrm{dm}^{-3}$ $\mathrm{K} ; 6.7 \mathrm{cmol} \mathrm{dm} \mathrm{dm}^{-3} \mathrm{Ca} ; 2.6 \mathrm{cmol} \mathrm{\textrm {dm } ^ { - 3 }} \mathrm{Mg}$; $2026.5 \mathrm{mg} \mathrm{dm}^{-3} \mathrm{Fe}$; and $0.5 \mathrm{mg} \mathrm{dm}^{-3} \mathrm{Zn}$. Management practices were uniform and similar for both experiments. Fertilization was performed with $275 \mathrm{~kg} \mathrm{ha}^{-1}$ of the $\mathrm{N}-\mathrm{P}_{2} \mathrm{O}_{5}-\mathrm{K}_{2} \mathrm{O}$ 5-20-20 formula 
(urea - 45\% nitrogen; triple superphosphate - $18 \%$ $\mathrm{P}_{2} \mathrm{O}_{5}$; and potassium chloride $-60 \% \mathrm{~K}_{2} \mathrm{O}$ ) at furrow sowing, and $67 \mathrm{~kg} \mathrm{ha}^{-1}$ of urea (45\% nitrogen) were distributed at the growth stage of the first trifoliate leaf. No micronutrients were added to the fertilizers. The seeds were treated with a mixture of Maxim XL fungicide (Fludioxonil and Metalaxyl-M) and Cruiser insecticide (Thiamethoxam), both at a rate of $200 \mathrm{~mL}$ of product per $100 \mathrm{~kg}$ of seeds. Other management practices were applied according to the technical recommendations for the common bean crop in the southern region of Brazil (CTSBF, 2012).

The common bean was harvested at maturity, that is, when the pods dried and the grains had the typical color of each genotype. Grain harvesting and threshing were performed manually to avoid mechanical damage and contamination by metals. After removal of impurities, the grains were dried in the sun and, when necessary, in a forced-air oven at $40{ }^{\circ} \mathrm{C}$ until reaching an average moisture content of $13 \%$. The grains were kept in refrigeration $\left(0.5{ }^{\circ} \mathrm{C}\right.$ and $75 \%$ relative moisture) during the assessment period (one month).

Cooking time was determined using a Mattson cooker with 25 plungers. For this purpose, a sample of 25 grains per replicate was placed into a beaker, to which $50 \mathrm{~mL}$ of distilled water were added. After eight hours soaking at room temperature $\left(20 \pm 2{ }^{\circ} \mathrm{C}\right)$, the grains were removed and placed on the support plate of the apparatus, under the plungers. The Mattson cooker was then placed into a medium-size pan with $3 \mathrm{~L}$ of previously boiled distilled water. Subsequently, the beans were cooked in a domestic stove over moderate heat. The cooking time of each bean grain was identified by the fall of a plunger. The time required for the drop of each plunger of the Mattson cooker was recorded, and the mean drop time of the first 13 plungers was considered as the cooking time of each sample.

The concentrations of potassium, phosphorus, iron, zinc and copper were determined in samples of $30 \mathrm{~g}$ of raw grains randomly collected from each experimental plot. The samples were ground in a micromill to obtain a fine and homogeneous bean powder. A 0.5 -g subsample of the flour was used in the digestion process in a solution of nitric and perchloric acids, in a 3:1 volume ratio, following the procedure described by Miyazawa et al. (2009). Completion of digestion was indicated when $1 \mathrm{~mL}$ of a clear crystalline solution remained in the interior of the digester tube. The solution was transferred to a $50-\mathrm{mL}$ falcon tube and distilled water was added to reach a volume of $50 \mathrm{~mL}$. The samples were kept in refrigeration until the mineral concentrations were determined.

The potassium concentration was measured using a flame photometer at a wavelength of 660.0 $\mathrm{nm}$, whereas the phosphorus concentration was analyzed using an optical emission spectrophotometer at a wavelength of $660.0 \mathrm{~nm}$. The concentrations of iron, zinc and copper were determined in an atomic absorption spectrophotometer at the wavelengths of $248.30 \mathrm{~nm}$, $213.90 \mathrm{~nm}$ and $324.75 \mathrm{~nm}$, respectively.

The obtained data were subjected to individual and combined analyses of variance. Cooking time was transformed into seconds. Homogeneity of residual variances was evaluated by Hartley's F maximum test (CRUZ; REGAZZI; CARNEIRO, 2012). Data normality was analyzed by the Lilliefors test, at $5 \%$ probability. The F test ( $p$ value $<0.05$ ) was used to test the hypotheses of the main effects (genotype and environment) and the genotype $\times$ environment interaction, considering all effects as fixed, whereas the error was analyzed as a random effect. The Scott-Knott test was used to cluster the evaluated genotypes for each growing environment, considering each trait analyzed individually.

The multiplicative selection index (SUBANDI; COMPTON; EMPIG, 1973) was used to obtain heritability and genetic gain estimates and to select the superior Mesoamerican common bean genotypes based on cooking time and mineral concentration. For this purpose, a selection intensity of $25 \%$ was applied to select the four superior genotypes for the traits that showed a significant difference for genotype and/or genotype $\times$ environment interaction effect, on the average of two growing environments. Selection was performed aiming to reduce cooking time and increase the concentrations of potassium, phosphorus, iron, zinc and copper. The resulting data were entered into an Office Excel spreadsheet, and the statistical analyses were performed using Genes software (CRUZ, 2016).

\section{RESULTS AND DISCUSSION}

\section{Overall results and genetic variability for cooking time and mineral concentration}

The ratio of the largest to the smallest mean squared error $\left(\mathrm{MSr}^{+} / \mathrm{MSr}^{-}\right)$of individual analysis of variance was lower than seven for all evaluated traits in both experiments, i.e., residual variances were homogeneous, which allows a combined analysis of variance, according to Gomes (1990). All data exhibited a normal distribution.

A significant genotype $\times$ environment interaction was observed for all traits, except for phosphorus concentration, for which only the environment effect was significant (Table 1). Similarly, a significant genotype $\times$ environment interaction was detected for cooking time (FARINELLI; LEMOS, 2010; RIBEIRO et al., 2013a, b; PEREIRA et al., 2017; STECKLING et al., 2017) and mineral concentration (PEREIRA et al.,

Rev. Caatinga, Mossoró, v. 35, n. 1, p. 96 - 104, jan. - mar., 2022 
2011; HOSSAIN et al., 2013; STECKLING et al., 2017; ZILIO; SOUZA; COELHO, 2017) in common bean genotypes. Therefore, the cooking time and mineral concentration of different common bean genotypes varied according to the growing environments, which emphasizes the importance of considering the environmental variability between growing seasons and years for the same location where the experiments are conducted. This will allow greater efficiency in the selection of common bean lines with higher mineral concentration and fast cooking.

Table 1. Combined analysis of variance containing the degrees of freedom (DF), mean squares, mean and coefficient of variation $(\mathrm{CV} \%)$ for the following traits: cooking time (cooking, $\mathrm{s})$, concentrations of potassium $\left(\mathrm{K}, \mathrm{g} \mathrm{kg}^{-1}\right.$ of dry matter $\mathrm{DM})$, phosphorus $\left(\mathrm{P}, \mathrm{g} \mathrm{kg}^{-1} \mathrm{DM}\right)$, iron $\left(\mathrm{Fe}, \mathrm{mg} \mathrm{kg}^{-1} \mathrm{DM}\right)$, zinc $\left(\mathrm{Zn}, \mathrm{mg} \mathrm{kg}^{-1} \mathrm{DM}\right)$ and copper $\left(\mathrm{Cu}, \mathrm{mg} \mathrm{kg}^{-1}\right.$ of $\left.\mathrm{DM}\right)$ of 16 common bean inbred lines assessed in the years 2014 and 2016.

\begin{tabular}{lcrccccc}
\hline \multirow{2}{*}{ Source of variation } & \multirow{2}{*}{ DF } & \multicolumn{5}{c}{ Mean square } \\
\cline { 3 - 8 } & & Cooking & $\mathrm{K}$ & $\mathrm{P}$ & $\mathrm{Fe}$ & $\mathrm{Zn}$ & $\mathrm{Cu}$ \\
\hline Block/environment & 4 & 1973.07 & 1.35 & 2.06 & 439.48 & 18.64 & 1.86 \\
Genotype (G) & 15 & $163467.94^{*}$ & $1.27^{\text {ns }}$ & $0.35^{\text {ns }}$ & $367.48^{*}$ & $24.45^{*}$ & $2.49^{*}$ \\
Environment (E) & 1 & $211876.04^{*}$ & $0.03^{\text {ns }}$ & $21.15^{*}$ & $4.12^{\text {ns }}$ & $50.72^{\text {ns }}$ & $83.78^{*}$ \\
G $\times$ E & 15 & $89518.97^{*}$ & $3.08^{*}$ & $0.62^{\text {ns }}$ & $580.15^{*}$ & $22.19^{*}$ & $4.24^{*}$ \\
Residual & 60 & 11275.19 & 1.62 & 0.41 & 144.01 & 11.54 & 1.15 \\
\hline \multicolumn{1}{c}{ Mean } & & 861.46 & 13.65 & 4.64 & 85.88 & 26.77 & 8.11 \\
\multicolumn{1}{c}{ CV (\%) } & & 12.33 & 9.32 & 13.76 & 13.97 & 12.69 & 13.21 \\
\hline
\end{tabular}

*Significant by the $\mathrm{F}$ test at $5 \%$ probability. ns: not significant.

The coefficient of variation ranged from 9.32 to $13.97 \%$, which were similar to the variation range previously described for cooking time (FARINELLI; LEMOS, 2010; RIBEIRO et al., 2013a, b; PERINA et al., 2014; PEREIRA et al., 2017; STECKLING et al., 2017) and mineral concentration (PEREIRA et al., 2011; STECKLING et al., 2017) determined in experiments with common bean. These coefficient of variation values can be considered low, indicating that fast-cooking Mesoamerican common bean lines biofortified with potassium, iron, zinc and copper can be selected with high experimental precision in the present study.

Lines DF 08-27, DF 08-24, DF 08-28, DF 07-11, DF 08-20 and DF 07-13 were clustered by the Scott-Knott test into the group of genotypes with the shortest cooking time ( $\leq 14 \mathrm{~min}$ and $50 \mathrm{~s})$ in both growing environments, which did not differ significantly from the control cultivars BRS Valente and Pérola (Table 2). Identifying common bean lines that require less than 30 min of cooking meets the demand of common bean consumers, and so it has been the standard pursued by breeding programs (PERINA et al., 2014; SILVA et al., 2016; PEREIRA et al., 2017). Recently, fast cooking was defined for common bean as less than $25 \mathrm{~min}$ (SANTOS; RIBEIRO; MAZIERO, 2016). However, breeding programs have selected common bean lines that can be cooked in up to $15 \mathrm{~min}$, in one or more growing environments (FARINELLI; LEMOS, 2010; RIBEIRO et al., 2013a, b; STECKLING et al., 2017). In the present study, six common bean lines, namely, DF 08-27, DF 08-24, DF 08-28, DF 07-11, DF 08-20 and DF 07-13, had a very short cooking time (up to $15 \mathrm{~min}$ ), i.e., they reached the softness considered suitable for consumption in half of the time that has been considered as the most acceptable standard by consumers.

Cultivar Guapo Brilhante showed the longest cooking time (29 min and $47 \mathrm{~s}$ ) in the dry season of 2016, differing significantly from the other genotypes. This can be explained by the fact that cultivar Guapo Brilhante has shiny grains, and when cultivated in environmental conditions with high rainfall, as in the dry season of 2016, this cultivar exhibited hard grains and a long cooking time.

The common bean genotypes were grouped into a single cluster for potassium concentration in the rainy season of 2014 and dry season of 2016 . However, all evaluated common bean genotypes exhibited a high potassium concentration in both growing environments, defined by Steckling et al. (2017) as $>12.00 \mathrm{~g} \mathrm{~kg}^{-1} \mathrm{DM}$, except for line DF $07-$ 13. Similarly, previous studies identified common bean genotypes with high potassium concentration (PEREIRA et al., 2011; SILVA et al., 2012; ZILIO; 
SOUZA; COELHO, 2017). In the present study, 12 common bean lines developed by UFSM were potassium-biofortified. The dietary use of potassiumbiofortified common bean lines is beneficial to health because potassium helps in the prevention of high blood pressure (EKMEKCIOUGLU et al., 2016).

Table 2. Mean values for cooking time (cooking, min:s) and concentrations of potassium ( $\mathrm{K}, \mathrm{g} \mathrm{kg}^{-1}$ of dry matter - DM), phosphorus ( $\left.\mathrm{P}, \mathrm{g} \mathrm{kg}^{-1} \mathrm{DM}\right)$, iron (Fe, mg kg-1 DM), zinc ( $\left.\mathrm{Zn}, \mathrm{mg} \mathrm{kg}^{-1} \mathrm{DM}\right)$ and copper ( $\mathrm{Cu}, \mathrm{mg} \mathrm{kg}^{-1}$ of DM) of 16 common bean inbred lines assessed in the years 2014 and 2016.

\begin{tabular}{|c|c|c|c|c|c|c|c|}
\hline \multirow{2}{*}{ Genotype } & \multirow{2}{*}{$\mathrm{G}^{1}$} & \multicolumn{2}{|c|}{ Cooking } & \multicolumn{2}{|c|}{$\mathrm{K}$} & \multicolumn{2}{|c|}{$\mathrm{P}$} \\
\hline & & 2014 & 2016 & 2014 & 2016 & 2014 & 2016 \\
\hline DF $08-23$ & B & $19: 15 \mathrm{a}^{*}$ & $13: 01 \mathrm{~b}$ & $13.35 \mathrm{a}$ & $14.44 \mathrm{a}$ & $3.81^{\mathrm{ns}}$ & $5.52^{\mathrm{ns}}$ \\
\hline Guapo Brilhante & $\mathrm{B}$ & $17: 56 \mathrm{a}$ & $29: 47$ a & $14.30 \mathrm{a}$ & $13.89 \mathrm{a}$ & 3.38 & 5.33 \\
\hline DF $07-10$ & B & $17: 29$ a & $12: 15 \mathrm{~b}$ & $13.53 \mathrm{a}$ & $13.15 \mathrm{a}$ & 4.02 & 5.47 \\
\hline DF 08-21 & B & $16: 42 \mathrm{a}$ & $13: 01 \mathrm{~b}$ & $14.30 \mathrm{a}$ & $14.17 \mathrm{a}$ & 4.63 & 5.39 \\
\hline DF 07-12 & $\mathrm{B}$ & $16: 22 \mathrm{a}$ & $12: 57 \mathrm{~b}$ & $12.61 \mathrm{a}$ & $14.07 \mathrm{a}$ & 3.95 & 4.96 \\
\hline DF 08-22 & $\mathrm{B}$ & $15: 36 \mathrm{a}$ & $12: 35 \mathrm{~b}$ & $13.97 \mathrm{a}$ & $12.78 \mathrm{a}$ & 3.90 & 4.86 \\
\hline DF 08-26 & B & $15: 34 \mathrm{a}$ & $13: 25 \mathrm{~b}$ & $14.52 \mathrm{a}$ & $13.33 \mathrm{a}$ & 4.60 & 5.07 \\
\hline DF 08-29 & B & $15: 25 \mathrm{a}$ & $11: 04 \mathrm{~b}$ & $14.01 \mathrm{a}$ & $13.33 \mathrm{a}$ & 4.66 & 5.29 \\
\hline DF 08-27 & $\mathrm{B}$ & $14: 50 \mathrm{~b}$ & $11: 47 \mathrm{~b}$ & $14.74 \mathrm{a}$ & $13.33 \mathrm{a}$ & 3.95 & 4.38 \\
\hline BRS Valente & $\mathrm{B}$ & $14: 48 \mathrm{~b}$ & $12: 24 b$ & $13.49 \mathrm{a}$ & $13.15 \mathrm{a}$ & 4.21 & 5.35 \\
\hline DF 08-24 & $\mathrm{C}$ & $13: 43 \mathrm{~b}$ & $13: 43 \mathrm{~b}$ & $13.75 \mathrm{a}$ & $13.89 \mathrm{a}$ & 3.81 & 5.18 \\
\hline DF 08-28 & B & $13: 23 \mathrm{~b}$ & $11: 21 \mathrm{~b}$ & $13.27 \mathrm{a}$ & $13.33 \mathrm{a}$ & 5.11 & 4.49 \\
\hline DF 07-11 & B & $13: 15 \mathrm{~b}$ & $11: 22 b$ & $15.25 \mathrm{a}$ & $13.52 \mathrm{a}$ & 4.46 & 5.00 \\
\hline DF 08-20 & B & $12: 52 \mathrm{~b}$ & $12: 36 \mathrm{~b}$ & $13.86 \mathrm{a}$ & $13.89 \mathrm{a}$ & 4.66 & 5.01 \\
\hline Pérola & $\mathrm{C}$ & $12: 42 \mathrm{~b}$ & $12: 38 \mathrm{~b}$ & $13.27 \mathrm{a}$ & $13.06 \mathrm{a}$ & 3.87 & 5.21 \\
\hline DF 07-13 & $\mathrm{C}$ & $12: 24 \mathrm{~b}$ & $13: 17 \mathrm{~b}$ & $10.49 \mathrm{a}$ & $14.81 \mathrm{a}$ & 3.66 & 5.21 \\
\hline Mean & & $15: 08$ & $13: 34$ & 13.67 & 13.63 & 4.17 & 5.11 \\
\hline $\mathrm{CV}(\%)$ & & 14.01 & 9.78 & 10.21 & 8.33 & 15.96 & 11.94 \\
\hline \multirow{2}{*}{ Genotype } & & \multicolumn{2}{|c|}{$\mathrm{Fe}$} & \multicolumn{2}{|c|}{$\mathrm{Zn}$} & \multicolumn{2}{|c|}{$\mathrm{Cu}$} \\
\hline & & 2014 & 2016 & 2014 & 2016 & 2014 & 2016 \\
\hline DF $08-23$ & B & $64.51 \mathrm{~b}$ & $96.80 \mathrm{a}$ & $21.54 \mathrm{~b}$ & $25.35 \mathrm{a}$ & $6.32 \mathrm{~b}$ & $7.85 \mathrm{a}$ \\
\hline Guapo Brilhante & B & $106.13 \mathrm{a}$ & $79.70 \mathrm{~b}$ & $28.76 \mathrm{a}$ & $24.12 \mathrm{a}$ & $10.52 \mathrm{a}$ & $6.48 \mathrm{a}$ \\
\hline DF 07-10 & B & 89.60 a & $92.45 \mathrm{a}$ & $32.87 \mathrm{a}$ & $29.83 \mathrm{a}$ & $8.58 \mathrm{~b}$ & $7.14 \mathrm{a}$ \\
\hline DF 08-21 & B & $94.15 \mathrm{a}$ & $96.75 \mathrm{a}$ & $29.05 \mathrm{a}$ & $27.02 \mathrm{a}$ & $11.85 \mathrm{a}$ & $7.98 \mathrm{a}$ \\
\hline DF 07-12 & B & $64.61 \mathrm{~b}$ & $92.17 \mathrm{a}$ & $23.15 \mathrm{~b}$ & $27.36 \mathrm{a}$ & $8.59 \mathrm{~b}$ & $7.67 \mathrm{a}$ \\
\hline DF 08-22 & B & $80.41 \mathrm{~b}$ & $74.68 \mathrm{~b}$ & $25.47 \mathrm{~b}$ & $24.86 \mathrm{a}$ & $9.55 \mathrm{a}$ & $6.24 \mathrm{a}$ \\
\hline DF 08-26 & B & $92.27 \mathrm{a}$ & $77.97 \mathrm{~b}$ & $31.05 \mathrm{a}$ & $26.55 \mathrm{a}$ & $10.05 \mathrm{a}$ & $7.00 \mathrm{a}$ \\
\hline DF 08-29 & B & $100.22 \mathrm{a}$ & $76.72 \mathrm{~b}$ & $32.24 \mathrm{a}$ & $23.58 \mathrm{a}$ & $8.07 \mathrm{~b}$ & $7.30 \mathrm{a}$ \\
\hline DF 08-27 & B & $77.14 \mathrm{~b}$ & $74.43 \mathrm{~b}$ & $27.47 \mathrm{~b}$ & $23.67 \mathrm{a}$ & $9.08 \mathrm{~b}$ & $6.75 \mathrm{a}$ \\
\hline BRS Valente & B & $67.97 \mathrm{~b}$ & $84.12 \mathrm{~b}$ & $26.77 \mathrm{~b}$ & $25.48 \mathrm{a}$ & $8.60 \mathrm{~b}$ & $7.44 \mathrm{a}$ \\
\hline DF 08-24 & $\mathrm{C}$ & $72.73 \mathrm{~b}$ & $75.65 \mathrm{~b}$ & $24.17 \mathrm{~b}$ & $28.25 \mathrm{a}$ & $8.32 \mathrm{~b}$ & $6.57 \mathrm{a}$ \\
\hline DF 08-28 & B & $106.07 \mathrm{a}$ & $73.87 \mathrm{~b}$ & $30.64 \mathrm{a}$ & $24.11 \mathrm{a}$ & $10.39 \mathrm{a}$ & $6.83 \mathrm{a}$ \\
\hline DF 07-11 & B & 87.99 a & $95.27 \mathrm{a}$ & $29.36 \mathrm{a}$ & $29.28 \mathrm{a}$ & $8.17 \mathrm{~b}$ & $8.16 \mathrm{a}$ \\
\hline DF $08-20$ & B & $99.00 \mathrm{a}$ & $100.44 \mathrm{a}$ & $26.54 \mathrm{~b}$ & $23.54 \mathrm{a}$ & $10.61 \mathrm{a}$ & $6.61 \mathrm{a}$ \\
\hline Pérola & $\mathrm{C}$ & $94.64 \mathrm{a}$ & $81.92 \mathrm{~b}$ & $24.72 \mathrm{~b}$ & $24.65 \mathrm{a}$ & $8.59 \mathrm{~b}$ & $7.10 \mathrm{a}$ \\
\hline DF 07-13 & $\mathrm{C}$ & $73.27 \mathrm{~b}$ & $104.40 \mathrm{a}$ & $26.16 \mathrm{~b}$ & $29.06 \mathrm{a}$ & $7.48 \mathrm{~b}$ & $7.75 \mathrm{a}$ \\
\hline Mean & & 85.67 & 86.08 & 27.50 & 26.04 & 9.05 & 7.18 \\
\hline $\mathrm{CV}(\%)$ & & 13.75 & 14.19 & 13.80 & 11.31 & 14.04 & 11.51 \\
\hline
\end{tabular}

*Means not followed by the same letter in the column differ by the Scott-Knott test $(p=0.05)$. ns: not significant.

${ }^{1} \mathrm{G}$ : group - B: black beans; C: carioca beans. 
The highest mean phosphorus concentration was found in the dry season of $2016\left(5.11 \mathrm{~g} \mathrm{~kg}^{-1}\right.$ DM). However, no common bean line exhibited high phosphorus concentration in both growing environments, that is, $>5.00 \mathrm{~g} \mathrm{~kg}^{-1} \mathrm{DM}$, according to Steckling et al. (2017). Thus, no phosphorusbiofortified common bean lines were obtained, corroborating the results reported by Ribeiro et al. (2019) in Mesoamerican common bean. These results indicate that there is less genetic variability for phosphorus concentration in the carioca and black bean cultivars.

Four common bean lines, namely, DF 07-10, DF 08-21, DF 07-11 and DF 08-20, comprised the genotypes group with the highest iron concentration values (87.99 to $\left.100.44 \mathrm{mg} \mathrm{kg}^{-1} \mathrm{DM}\right)$ for both growing environments. Breeding programs have obtained common bean lines with high iron concentration, that is, $>95 \mathrm{mg} \mathrm{kg}^{-1} \mathrm{DM}$, according to the classes defined by Ribeiro et al. (2013a) (AKOND et al., 2011; SILVA et al., 2012; STECKLING et al., 2017; RIBEIRO et al., 2019). In the present study, only line DF 08-20 showed a high iron concentration ( $>95 \mathrm{mg} \mathrm{kg}^{-1} \mathrm{DM}$ ) in both growing environments. Selection and inclusion of new common bean cultivars with high iron concentration in the diet is recommended to reduce the incidence of anemia, which causes symptoms such as tiredness and weakness due to an inadequate supply of oxygen to the human body cells (ALFARTUSIE; MOHSSAN, 2017).

Lines DF 07-10, DF 08-21, DF 08-26, DF 08-29, DF 08-28 and DF 07-11 and cultivar Guapo Brilhante exhibited the highest zinc concentration values (28.76 to $32.87 \mathrm{mg} \mathrm{kg}^{-1} \mathrm{DM}$ ) in the rainy season of 2014. In the dry season of 2016, a single group of common bean genotypes was obtained for zinc concentration by the Scott-Knott test. Breeding programs have developed common bean genotypes with high zinc concentration, defined as $>31 \mathrm{mg} \mathrm{kg}^{-1} \mathrm{DM}$ by Tryphone and NchimbiMsolla (2010) (SILVA et al., 2012; PEREIRA et al., 2014; MAZIERO; RIBEIRO; STORCK, 2015; MARTINS et al., 2016). In the present study, common bean lines with high zinc concentration were identified only in the rainy season of 2014, namely, DF 07-10, DF 08-26 and DF 08-29. Consumption of common bean cultivars with high zinc concentration is important to prevent diseases such as anorexia, depression and dermatitis (SOUSA et al., 2019).

With regard to the copper concentration, genotype stratification only occurred in the rainy season of 2014, similarly to the zinc concentration. The genotype group with the highest copper concentration values, which ranged from 9.55 to
$11.85 \mathrm{mg} \mathrm{kg}^{-1} \mathrm{DM}$, also included lines DF 08-21, DF 08-22, DF 08-26, DF 08-28 and DF 08-20 and cultivar Guapo Brilhante. For common bean, no previous studies were found in the literature that defined values that characterize a high copper concentration. However, consumption of common bean genotypes with a higher copper concentration, such as DF 08-21, DF 08-22, DF 08-26, DF 08-28, DF $08-20$ and Guapo Brilhante, is healthy, since copper helps to prevent anemia and fatigue and maintain white blood cells (AL-FARTUSIE; MOHSSAN, 2017).

In the case of a significant genotype $x$ environment interaction for cooking time and mineral concentration, the selection of superior common bean lines becomes more difficult. This is because the ranking of the best common bean lines will not be the same for all evaluated traits in different environments, as observed in the present study. For this reason, the use of the selection index, considering the mean data obtained in the growing environments, helps identify superior common bean lines for various traits simultaneously.

\section{Simultaneous selection for fast cooking and high mineral concentration}

The multiplicative index was used for a simultaneous selection (SUBANDI; COMPTON; EMPIG, 1973) aiming to reduce cooking time and increase the concentrations of potassium, iron, zinc and copper. Phosphorus concentration was not included in these analyses because no genetic variability was observed for this mineral (Table 1).

The results obtained by using the multiplicative index showed intermediate to high heritability $\left(h^{2}: 52.80\right.$ to $\left.93.10 \%\right)$ and genetic gain estimates favorable to the selection of fast-cooking common bean lines $(-8.39 \%)$ biofortified with iron (5.89\%), zinc (1.32\%) and copper (4.72\%) (Table 3$)$. These results indicate ease of selection due to a greater contribution of genetic variance to the expression of these traits, which contributes to greater progress in the selection. The use of multiplicative index also resulted in positive genetic gain estimates for iron and zinc concentrations in populations of recombinant inbred lines (RIL) of Mesoamerican common bean evaluated by Jost et al. (2012) and Maziero, Ribeiro and Storck (2015), respectively. Similarly, Ribeiro et al. (2019) obtained genetic gain estimates favorable to increased iron and zinc concentrations in a RIL population of Mesoamerican common bean. For cooking time and copper concentration, no previous studies of genetic gain estimated by the selection index were found in the literature for common bean lines. 
Table 3. Mean of the original population $\left(X_{0}\right)$, mean of selected genotypes $\left(X_{S}\right)$, heritability $\left(h^{2} \%\right)$, genetic gain $(G G)$, and percentage of genetic gain (GG\%) with simultaneous selection by the multiplicative index for the following traits: cooking time (min:s) and concentrations of potassium ( $\mathrm{K}, \mathrm{g} \mathrm{kg}^{-1}$ of dry matter - DM), iron (Fe, mg kg$\left.{ }^{-1} \mathrm{DM}\right)$, zinc $\left(\mathrm{Zn}, \mathrm{mg} \mathrm{kg}^{-1} \mathrm{DM}\right)$ and copper $\left(\mathrm{Cu}, \mathrm{mg} \mathrm{kg}^{-1}\right.$ of $\left.\mathrm{DM}\right)$ in the selected four superior common bean inbred lines, considering the mean values obtained for the two experiments.

\begin{tabular}{|c|c|c|c|c|c|c|c|c|c|}
\hline \multirow{2}{*}{ Trait } & \multirow{2}{*}{$\mathrm{X}_{0}$} & \multirow{2}{*}{$\mathrm{X}_{\mathrm{s}}$} & \multirow{2}{*}{$\mathrm{h}^{2 \%} \%$} & \multirow{2}{*}{ GG } & \multirow{2}{*}{$\mathrm{GG} \%$} & \multicolumn{4}{|c|}{ Selected inbred line } \\
\hline & & & & & & DF 07-11 & DF $08-21$ & DF $08-20$ & DF 08-28 \\
\hline Cooking & $14: 21$ & 13:04 & 93.10 & -72.27 & -8.39 & $12: 18$ & $14: 51$ & $12: 44$ & $12: 22$ \\
\hline K & 13.65 & 13.95 & 0.00 & 0.00 & 0.00 & 14.39 & 14.23 & 13.87 & 13.30 \\
\hline $\mathrm{Fe}$ & 85.88 & 94.19 & 60.81 & 5.06 & 5.89 & 91.63 & 95.45 & 99.72 & 89.97 \\
\hline $\mathrm{Zn}$ & 26.77 & 27.44 & 52.80 & 0.35 & 1.32 & 29.32 & 28.04 & 25.04 & 27.38 \\
\hline $\mathrm{Cu}$ & 8.11 & 8.82 & 53.93 & 0.38 & 4.72 & 8.16 & 9.92 & 8.61 & 8.61 \\
\hline
\end{tabular}

However, negative genetic variance was obtained for potassium concentration, resulting in zero heritability and genetic gain estimates. Thus, environmental variance was the main component of phenotypic variance for this mineral. In contrast, Maziero, Ribeiro and Storck (2015) found a genetic gain of $1.81 \%$ for potassium concentration when the multiplicative index was used to identify superior lines among the 169 common bean lines evaluated in two growing seasons. The differences reported can be explained by the diversity of the germplasm studied and the growing conditions, where the importance of obtaining genetic parameters in common-bean breeding programs should be highlighted.

The application of the multiplicative index allowed selecting the four superior common bean lines for cooking time and mineral concentration, namely, DF 07-11, DF 08-21, DF 08-20 and DF 0828. These common bean lines showed a very short cooking time (up to $15 \mathrm{~min}$ ), high potassium concentration $\left(>12.00 \mathrm{~g} \mathrm{~kg}^{-1} \mathrm{DM}\right)$ and the highest mean values of micromineral (iron, zinc and copper) concentration. Lines DF 08-21 and DF 08-20 also showed high iron concentration $\left(>95.00 \mathrm{mg} \mathrm{kg}^{-1}\right.$ $\mathrm{DM})$; these lines have a very short cooking time and are biofortified with potassium and iron and, therefore, promising for selection by the breeding program.

The use of the multiplicative index resulted in favorable genetic gain estimates for all agronomic and mineral traits (JOST et al., 2012; MAZIERO; RIBEIRO; STORCK, 2015) and technological quality traits (ARNS et al., 2018) considered important in the selection of common bean cultivars. In addition, unlike other methods the multiplicative index does not require economic weights to be established, which makes its use extremely simple in the routine of a breeding program. In the present study, the multiplicative index was considered an excellent selection strategy to be implemented in the breeding program when aiming at the simultaneous selection of fast-cooking, mineral-biofortified cultivars of common bean.

\section{CONCLUSIONS}

The Mesoamerican common-bean lines differ for cooking time and the concentrations of potassium, iron, zinc and copper. The ranking of the superior common bean lines is not the same for all evaluated traits in different environments, when the Scott-Knott test is used.

The application of the multiplicative index enables the selection of superior common bean lines for all traits, namely, DF 07-11, DF 08-21, DF 08-20 and DF 08-28. These lines exhibit a very short cooking time (up to $15 \mathrm{~min}$ ), high potassium concentration ( $>12.00 \mathrm{~g} \mathrm{~kg}^{-1}$ of dry matter) and the highest mean values of micromineral concentration and will thus be selected by the breeding program.

\section{ACKNOWLEDGEMENTS}

Thanks are extended to the National Council for Scientific and Technological Development (CNPq) for financial support and scholarships. The authors would also like to thank Mr. Henrique Caletti Mezzomo for his assistance in conducting the experiments.

\section{REFERENCES}

AKOND, A. S. M. G. M. et al. Minerals (Zn, Fe, Ca and $\mathrm{Mg}$ ) and antinutrient (phytic acid) constituent in common bean. American Journal of Food Technology, 6: 235-243, 2011.

AL-FARTUSIE, F.; MOHSSAN, S. N. Essential trace elements and their vital roles in human body. Indian Journal of Advances in Chemical Science, 


\section{5: 127-136, 2017}

ARNS, F. D. et al. Combined selection in carioca beans for grain size, slow darkening and fast-cooking after storage times. Euphytica, 214: 1-12, 2018.

CHÁVEZ-MENDOZA, C.; SÁNCHEZ, E. Bioactive compounds from Mexican varieties of common bean (Phaseolus vulgaris): implications for health. Molecules, 22: 1-32, 2017.

CRUZ, C. D. Genes Software - extended and integrated with the R, Matlab and Selegen. Acta Scientiarum. Agronomy, 38: 547-552, 2016.

CRUZ, C. D.; REGAZZI, A. J.; CARNEIRO, P. C. $\mathrm{S}$. Modelos biométricos aplicados ao melhoramento genético. 3. ed. Viçosa, MG: UFV, 2012. $480 \mathrm{p}$.

CTSBF - Comissão Técnica Sul Brasileira de Feijão. Informações técnicas para o cultivo de feijão na Região Sul Brasileira 2012. Florianópolis, SC: EPAGRI, 2012. 157 p

EKMEKCIOGLU, C. et al. The role of dietary potassium in hypertension and diabetes. Journal of Physiology and Biochemistry, 72: 93-106, 2016.

FARINELLI, R.; LEMOS, L. B. Qualidade nutricional e tecnológica de genótipos de feijão cultivados em diferentes safras agrícolas. Bragantia, 69: 759-763, 2010.

GOMES, F. P. Curso de estatística experimental. 13. ed. Piracicaba, SP: Nobel, 1990. 468 p.

HOSSAIN, K. G. et al. Interdependence of genotype and growing site on seed mineral compositions in common bean. Asian Journal of Plant Sciences, 12: 11-20, 2013.

JOST, E. et al. Comparison among direct, indirect and index selections on agronomic traits and nutritional quality traits in common bean. Journal of the Science of Food and Agriculture, 93: 10971104, 2012.

MAPA - Ministério da Agricultura, Pecuária e Abastecimento. Plano nacional para o desenvolvimento da cadeia produtiva do feijão e pulses. Brasília, DF, 2018. 20 p. Disponível em: $<$ http://www.agricultura.gov.br/assuntos/camarassetoriais-tematicas/documentos/camaras-setoriais/ feijao/2018/4a-re/minuta-pndcpfp-indicacaocontribuicoes-versao-02-02-2018.pdf $>$. Acesso em: 04 jan. 2021.

MARTINS, S. M. et al. Genetic parameters and breeding strategies for high levels of iron and zinc in
Phaseolus vulgaris L. Genetics and Molecular Research, 15: 1-11, 2016.

MAZIERO, S. M.; RIBEIRO, N. D.; STORCK, L. Simultaneous selection in beans for architecture, grain yield and minerals concentration. Euphytica, 205: 369-380, 2015

MIYAZAWA, M. et al. Análise química de tecido vegetal. In: SILVA, F. C. (Ed.). Manual de análises químicas de solos, plantas e fertilizantes. 2. ed. Brasília, DF: Embrapa Informação Tecnológica, 2009, cap. 4, p. 191-234.

PEREIRA, H. S. et al. Genetic variability for iron and zinc content in common bean lines and interaction with water availability. Genetics and Molecular Research, 13: 6773-6785, 2014.

PEREIRA, H. S. et al. Culinary and nutritional quality of common bean lines with Carioca grain type and interaction with environments. Revista Ceres, 64: 159-166, 2017.

PEREIRA, T. et al. Diversidade no teor de nutrientes em grãos de feijão crioulo no Estado de Santa Catarina. Acta Scientiarum Agronomy, 33: 477 $485,2011$.

PERINA, E. F. et al. Technological quality of common bean grains obtained in different growing seasons. Bragantia, 73: 14-22, 2014.

PRAVST, I. Risking public health by approving some health claims? - The case of phosphorus. Food Policy, 36: 726-728, 2011.

RIBEIRO, N. D. et al. Selection of common bean lines with high agronomic performance and high calcium and iron concentrations. Pesquisa Agropecuária Brasileira, 48: 1368-1375, 2013a.

RIBEIRO, N. D. et al. Combined selection for grain yield, cooking quality and minerals in the common bean. Revista Ciência Agronômica, 44: 869-877, $2013 b$.

RIBEIRO, N. D. et al. Genetic parameters and combined selection for phosphorus, phytate, iron, and zinc in Mesoamerican common bean lines. Ciência e Agrotecnologia, 43: 1-13, 2019.

RIBEIRO, N. D.; MEZZOMO, H. C.; SANTOS, G. G. dos. Genetic parameters and combined selection for seed coat color and macrominerals in Mesoamerican common bean lines. Genetics and Molecular Research, 18: 1-14, 2019.

SANTOS, G. G.; RIBEIRO, N. D.; MAZIERO, S. $\mathrm{M}$. Evaluation of common bean morphological traits 
identifies grain thickness directly correlated with cooking time. Pesquisa Agropecuária Tropical, 46: 35-42, 2016.

SILVA, C. A. et al. Chemical composition as related to seed color of common bean. Crop Breeding and Applied Biotechnology, 12: 132-137, 2012.

SILVA, M. B. O. et al. Technological quality of grains of common beans selected genotypes from the carioca group. Semina: Ciências Agrárias, 37: 1721 $-732,2016$.

SOUSA, C. et al. Trace minerals in human health: iron, zinc, copper, manganese and fluorine. International Journal of Science and Research Methodology, 13: 57- 80, 2019.

STECKLING, S. M. et al. Genetic diversity and selection of common bean lines based on technological quality and biofortification. Genetics and Molecular Research, 16: 1-13, 2017.

SUÁREZ-MARTÍNEZ, S. E. et al. Bean seeds: leading nutraceutical source for human health. CyTA-Journal of Food, 14: 131-137, 2016.

SUBANDI, W.; COMPTON, A.; EMPIG, L. T. Comparison of the efficiencies of selection indices for three traits in two variety crosses of corn. Crop Science, 13: 184-186, 1973.

TRYPHONE, G. M.; NCHIMBI-MSOLLA, S. Diversity of common bean (Phaseolus vulgaris L.) genotypes in iron and zinc contents under screenhouse conditions. African Journal of Agricultural Research, 5: 738-747, 2010.

ZILIO, M.; SOUZA, C. A.; COELHO, C. M. M. Phenotypic diversity of nutrients and anti-nutrients in bean grains grown in different locations. Revista Brasileira de Ciências Agrárias, 12: 528-534, 2017. 